๑ Open Access Full Text Article

ERRATUM

\title{
Combined letrozole and clomiphene versus letrozole and clomiphene alone in infertile patients with polycystic ovary syndrome [Erratum]
}

Hajishafiha M, Dehghan M, Kiarang N, etal. Combined letrozole and clomiphene versus letrozole and clomiphene alone in infertile patients with polycystic ovary syndrome. Drug Design, Development and Therapy. 2013;7:1427-1431.
The publishing details are erroneously reported at 2014; 8:1427-1431, when in fact the paper is published in Drug Design, Development and Therapy, 2013;7:1427-1431.
Drug Design, Development and Therapy is an international, peerreviewed open-access journal that spans the spectrum of drug design and development through to clinical applications. Clinical outcomes, patient safety, and programs for the development and effective, safe, and sustained use of medicines are the features of the journal, which has also been accepted for indexing on PubMed Central. The manuscript management system is completely online and includes a very quick and fair peer-review system, which is all easy to use. Visit http://www.dovepress.com/testimonials.php to read real quotes from published authors. 